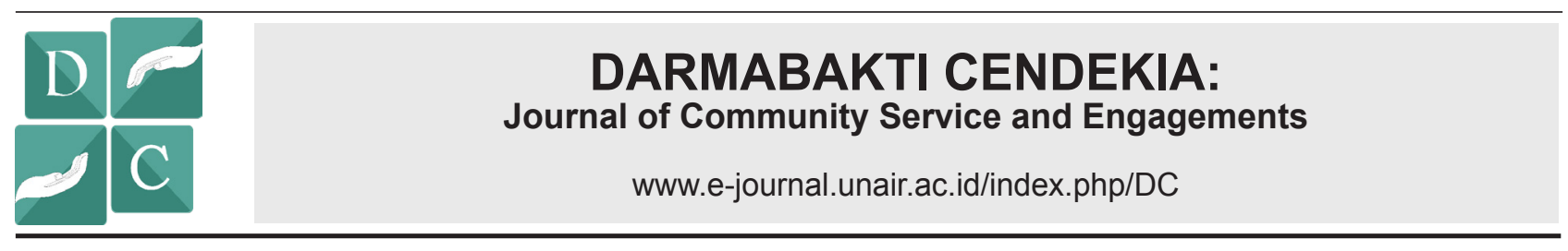

\title{
COUNSELING ABOUT DISINFECTION DURING REPAIR OF ACRYLIC RESIN DENTURES AT DENTAL LABORATORIES IN MALANG AND KEDIRI
}

\author{
SOSIALISASI DESINFEKSI SAAT REPARASI GIGI TIRUAN RESIN \\ AKRILIK PADA LABORATORIUM GIGI DI MALANG DAN KEDIRI
}

Scope:

Health

Dwiyanti Feriana Ratwita

Study Programme of Dental Technique, Faculty of Vocational Studies, Universitas Airlangga, Surabaya-Indonesia

\begin{abstract}
$A B S T R A C T$
Background: Sometimes the artificial teeth break or fracture, so then the patient asks the dentist to repair it. The dentist will then send the denture to be repaired by a dental technician in the dental laboratory. The transfer of work is likely to pose a risk of cross infection (for example: AIDS, hepatitis, tuberculosis, pneumonia and herpes. Objective: To transfer knowledge and technology of dentistry based on community needs objectively to obtain a strong foundation in carrying out health management of dental technicians. Method: Providing counseling to dental technicians on how to use disinfection materials and using props accompanied by interactive discussion. Results: Implementation this programs is conducted at 2 locations in the city of Malang and Kediri Counseling is done by providing knowledge about how to disinfect dentures using chlorhexidine material by spraying it on the entire surface of the denture. Conclusion: The counseling activity which was held for a day received good reception from the participants. The dedication report was prepared to be a reference material in raising awareness of $t$ dental technicians who work in dental laboratories to avoid cross-infection when doing denture repair.
\end{abstract}

\section{A B S T R A K}

Latar belakang: Kadangkala gigi tiruan pecah atau patah, sehingga kemudian pasien minta dokter gigi untuk memperbaikinya. Dokter gigi selanjutnya akan mengirimkan gigi tiruan tersebut untuk direparasi oleh teknisi gigi di laboratorium gigi. Pemindahan pekerjaan tersebut kemungkinan dapat menimbulkan resiko infeksi silang seperti AIDS, hepatitis, TBC, pneumonia dan herpes. Tujuan: Melakukan transfer ilmu pengetahuan dan teknologi kedokteran gigi berbasis kebutuhan masyarakat secara obyektif untuk mendapatkan fondasi yang cukup kuat dalam melaksanakan pengelolaan kesehatan pada teknisi gigi secara mandiri. Metode: Memberikan penyuluhan kepada teknisi gigi tentang cara menggunakan bahan desinfeksi serta menggunakan alat peraga disertai diskusi interaktif. Hasil: Pelaksanaan program dilakukan pada 2 lokasi yaitu di Malang dan Kediri. Penyuluhan dilakukan dengan memberikan pengetahuan tentang cara melakukan desinfeksi pada gigi tiruan dengan menggunakan bahan khlorheksidin dengan cara disemprot pada seluruh permukaan gigi tiruan. Kesimpulan: Kegiatan penyuluhan yang diselenggarakan selama sehari, mendapat sambutan yang baik dari peserta. Laporan pengabdian ini disusun untuk menjadi bahan acuan dalam meningkatkan kesadaran teknisi gigi yang bekerja di laboratorium gigi untuk menghindari terjadinya infeksi silang pada saat melakukan tindakan reparasi gigi tiruan.

\author{
ART I CLE INFO \\ Recieved 9 Desember 2019 \\ Accepted 13 Juni 2020 \\ Online 6 Desember 2020 \\ *Correspondence (Korespondensi): \\ Dwiyanti Feriana Ratwita \\ E-mail: \\ dwiyantiferiana@gmail.com
}

Keywords:

Desinfeksi; Gigi tiruan; Resin akrilik; Laboratorium gigi

Kata kunci:

Disinfection, Denture; Acrylic resin; Dental laboratory 


\section{PENDAHULUAN}

Resin akrilik polimetil metakrilat (PMMA) adalah salah satu bahan yang sampai saat ini masih banyak digunakan dalam bidang ilmu gigi tiruan terutama sebagai basis gigi tiruan. Polimetil metakrilat murni tidak berwarna, transparan dan padat, tidak toksik, tidak iritasi, tidak larut dalam cairan mulut, estetik baik, mudah dimanipulasi, reparasinya mudah dan perubahan dimensinya kecil. Namun resin akrilik ini mempunyai kekurangan yaitu mudah pecah bila jatuh pada permukaan keras atau akibat kelelahan bahan karena lama pemakaian serta mengalami perubahan warna setelah beberapa waktu dipakai dalam mulut, oleh karena itu diperlukan reparasi (Al-Fahdawi, 2009; David, 2005).

Dokter gigi yang mendapat keluhan dari pasien karena pecahnya basis gigi tiruan resin akrilik tersebut akan mengirimkan gigi tiruan itu untuk di reparasi oleh teknisi gigi di laboratorium gigi. Pemindahan pekerjaan tersebut kemungkinan dapat menimbulkan resiko infeksi silang dari klinik gigi ke laboratorium gigi (Badrian, 2012; Salviaa, 2013). Resiko infeksi silang tersebut dapat menimbulkan rasa kekhawatiran pada teknisi gigi. Beberapa studi mengemukakan tentang adanya kontaminasi pada proses penyerahan ke teknisi gigi oleh dokter gigi. Dugaan kontaminasi tersebut berasal dari manipulasi protesa yang terkontaminasi oleh mikroorganisme (Sande, 1975).

Lingkungan gigi dikaitkan dengan sejumlah besar risiko paparan berbagai mikroorganisme. Pengendalian infeksi adalah salah satu elemen utama dari praktik gigi yang sukses. Ada banyak penyakit menular yang dapat ditularkan di lingkungan gigi. Penyakit baru dengan konsekuensi serius dan tingkat penularan yang tinggi telah berkembang di masa lalu. Pengendalian infeksi diarahkan pada pencegahan paparan infeksi tersebut dan juga untuk mencegahnya ditularkan dari orang ke orang. Kebijakan pengendalian infeksi universal menganggap bahwa setiap pasien harus dianggap infeksi (Shah, 2010).

Resistensi antimikroba telah menjadi prioritas kesehatan global yang mendesak. Praktek kebersihan dasar dan pembersihan dan desinfeksi lingkungan rumah sakit adalah kunci dalam mencegah transmisi silang patogen (Kenters,2018

Pengendalian infeksi silang dalam bidang kedokteran gigi sangat penting. Hal ini dikarenakan kekhawatiran tentang penularan infeksi penyakit menular seperti, AIDS, Hepatitis, TBC, Pneumonia dan Herpes antara pasien, dokter gigi dan teknisi gigi. Reparasi gigi tiruan dapat beresiko tertular infeksi dari protesa gigi tiruan tersebut. Untuk itu para teknisi gigi dan dokter gigi sepakat bahwa protesa gigi perlu didesinfeksi sebelum dilakukan tindakan reparasi dan juga sebelum dikembalikan ke dokter gigi (Hussen, 2008).

Penggunaan tindakan pencegahan pengendalian infeksi yang tepat penting untuk teknisi laboratorium gigi, seperti halnya untuk tim gigi. Penanganan barang yang terkontaminasi secara tidak benar, seperti tayangan, gips, dan peralatan buatan lainnya, dapat mengakibatkan kontaminasi silang dan kemungkinan infeksi silang pada personel. Ketika digunakan bersamasama, penggunaan rutin prosedur dan protokol pengendalian infeksi yang direkomendasikan, bersama dengan komunikasi yang efektif antara praktik gigi dan laboratorium gigi, dapat memberikan lingkungan kerja yang aman bagi mereka yang memiliki potensi risiko pekerjaan.

Pemaparan terdokumentasi historis dari para profesional perawatan kesehatan gigi dan pasien mereka terhadap berbagai bakteri, virus, dan mikroba patogen lainnya mengarah pada pengembangan pedoman pengendalian infeksi oleh Pusat Pengendalian dan Pencegahan Penyakit (CDC) dan American Dental Association (ADA) (Fluent,2013).

Para teknisi gigi juga harus menggunakan alat-alat pelindung untuk mengurangi resiko infeksi silang tersebut yaitu dengan menggunakan masker sebagai pelindung hidung dan mulut, memakai kacamata serta sarung tangan, sedangkan untuk persiapan reparasi gigi tiruan dilakukan pencegahan dengan menggunakan bahan desinfektan. Bahan desinfektan yang sering digunakan untuk desinfeksi gigi tiruan adalah klorheksidin dan larutan sodium hipoklorit (Anusavice, 2004). Resin akrilik adalah derivat dari etilen dan terdiri dari group vinil dengan rumus struktur yang sempurna. Adapun komposisi dari resin ini adalah bahan bubuk dan cairan. Bubuk ini memiliki sifat yang transparan atau mirip dengan warna gigi atau warna pink (dapat menyerupai gusi dan juga mirip dengan gambaran darah) (Anusavice, 2004; Manappallil, 1998; Powers, 2008; Mc Cabe, 1984; Noort, 2010).

Resistensi resin akrilik terhadap larutan yang mengandung asam atau basa lemah adalah baik. Penggunaan alkohol dapat menyebabkan retaknya gigi tiruan. Etanol juga berfungsi sebagai plasticizer dan dapat mengurangi temperatur transisi kaca. Oleh karena itu larutan yang mengandung alkohol sebaiknya tidak digunakan untuk desinfeksi gigi tiruan (Anusavice, 2004).

Gigitiruan resin akrilik mudah patah atau pecah bila jatuh pada permukaan yang keras atau akibat kelelahan bahan karena lama pemakaian serta mengalami perubahan warna setelah beberapa waktu dipakai didalam mulut (Al-Fahdawi, 2009). 
Gigi tiruan yang patah atau pecah memerlukan tindakan reparasi agar berfungsi kembali. Langkah persiapan yang dilakukan sebelum melakukan reparasi pada gigi tiruan adalah dengan melakukan desinfeksi pada gigi tiruan. Desinfeksi adalah membunuh mikroorganisme penyebab penyakit dengan bahan kimia atau secara fisik, hal ini dapat mengurangi kemungkinan terjadinya infeksi dengan jalan membunuh mikroorganisme patogen. Desinfektan yang tidak berbahaya bagi permukaan tubuh dan dapat digunakan dinamakan antiseptik (Hutasoit, 2010).

Antiseptik adalah zat yang dapat menghambat atau menghancurkan mikroorganisme pada jaringan hidup, sedang desinfektan digunakan pada benda mati. Desinfektan dapat pula digunakan sebagai antiseptik atau sebaliknya tergantung dari toksisitasnya. Antiseptik dan desinfektan digunakan secara luas di rumah sakit dan klinik. Secara khusus hal tersebut merupakan bagian penting dari pengendalian infeksi dan pencegahan infeksi nosokomial (Hutasoit, 2010; Mc Donnel, 1999).

Ada beberapa cara untuk mensterilkan atau membersihkan resinakrilik darikumanakibatinfeksi silang yaitu ada dalam saliva dan menggantikan kalsium yang diperlukan sebagai perekat dengan cara pertama yaitu dicelupkan ke dalam larutan desinfektan. Cara kedua dengan disemprot (spray) dengan bahan desinfektan, dan cara ketiga yaitu dengan menggunakan microwave. Untuk sterilisasi gigi tiruan, ADA merekomendasikan perendaman gigi tiruan dalam desinfektan. Bahan desinfektan yang direkomendasi oleh ADA adalah alkalin glutaraldehid sedangkan desinfektan yang lazim digunakan rumah sakit di Indonesia adalah klorheksidin dan sodium hipoklorit (Hussen, 2008). Klorheksidin adalah turunan bis-guanides yang merupakan agen kationik serta memiliki aktivitas sebagai fungisidal dan bakteridal terhadap organisme gram positif maupun gram negative. Klorheksidin terikat pada anionic groups pada permukaan bakteri, dan kemungkinan pada phosphate groups oftheichoic acid (dinding sel) pada bakteri gram positif dan phosphate groups of lipopolysaccharides (membran luar) pada bakteri gram negatif. Ketika ikatan bis-biguanides konsentrasi rendah yang bersifat bakteriostatik terikat pada organisme, membran sel bakteri menjadi permeabel, dan menjadikan kandungan sitoplasmik bocor. Pada konsentrasi yang tinggi klorheksidin bersifat bakteriosidal menyebabkan penggumpalan protein sitoplasmik (Ferraz, 2007; Yagiela, 2004). Klorheksidin mungkin adalah bahan yang paling banyak digunakan dalam produk antiseptik, khususnya di produk cuci tangan dan mulut tetapi juga sebagai disinfektan dan pengawet. Hal ini terutama disebabkan karena mempunyai spektrum kemanjuran yang luas, substantivitas untuk kulit, dan iritasi yang rendah (Mc Donnel, 1999). Klorheksidin merupakan basa kuat dan paling stabil dalam bentuk garam klorheksidin diglukonat yang larut dalam air. Klorheksidin sangat luas digunakan sebagai desinfektan karena memiliki sifat antimikroba yang baik terhadap gram positif, spora bakteri, virus lipofilik, jamur dan dermatofit (Tanumihardja, 2010).

Sodium hipoklorit merupakan salah satu desinfektan yang sangat aktif pada semua bakteri, virus, fungi, parasit dan spora. Sodium hipoklorit termasuk golongan halogenated yang oxygenating. Sodium hipoklorit dalam larutan membentuk hypochlorus acid $(\mathrm{HOCl})$ dan oxychloride $(\mathrm{OCl})$. Sodium hipoklorit (cairan pemutih, eau de javel, dll.) adalah desinfektan yang sempurna yang dapat membunuh bakteri, virus, murah dan tersedia secara luas (David, 2005). Karena melihat pentingnya tindakan desinfeksi pada gigi tiruan yang harus dilakukan saat reparasi gigi tiruan serta mengingat akibat-akibat yang ditimbulkan apabila tidak dilakukan desinfeksi pada saat reparasi gigi tiruan, maka sangat perlu dilakukan pengabdian masyarakat ini. Pengabdian Masyarakat ini bertujuan melakukan transfer ilmu pengetahuan dan teknologi kedokteran gigi dasar dan praktis berbasis kebutuhan masyarakat secara obyektif, mendapatkan fondasi yang cukup kuat dalam melaksanakan pengelolaan kesehatan para teknisi gigi secara mandiri. Adapun pada pelaksanaannya terbagi menjadi beberapa subkegiatan dengan tujuan yang sama sebagai berikut: Pelatihan dan penyuluhan penggunaan bahan desinfeksi pada laboratorium gigi di Surabaya dan Jember.

Tujuan dari program kemitraan masyarakat yang berupa Pelatihan dan Penyuluhan Desinfeksi saat Reparasi Gigi Tiruan Resin Akrilik pada Laboratorium Gigi di Surabaya dan Jember yaitu melakukan transfer ilmu kepada mitra mengenai pengendalian infeksi silang dalam bidang kedokteran gigi, karena hal tersebut sangat penting. Hal ini dikarenakan kekhawatiran tentang penularan infeksi penyakit menular seperti, AIDS, Hepatitis, TBC, Pneumonia dan Herpes antara pasien, dokter gigi dan teknisi gigi .

\section{Permasalahan Mitra}

Pencegahan penyakit dan promosi kesehatan merupakan upaya esensial di saat masih tingginya kejadian penyakit menular juga diiringi dengan semakin meningkatnya masalah penyakit tidak menular. Semakin tingginya beban masalah kesehatan masyarakat saat ini mengindikasikan 
bahwa promosi kesehatan dan pencegahan yang telah ada kurang dapat berkontribusi dalam meningkatkan derajat kesehatan masyarakat. Di Malang dan Kediri, belum dilakukan promosi kesehatan dan pencegahan penyakit di laboratorium gigi yang ada, sehingga perlu dilakukan inisiasi promosi kesehatan dan pencegahan penyakit yang berbasis masyarakat.

Manfaat dari program kemitraan masyarakat yang berupa Sosialisasi Penggunaan Desinfeksi saat Reparasi Gigi Tiruan Resin Akrilik pada Laboratorium Gigi di Malang dan Kediri yaitu untuk memberikan pemahaman kepada para teknisi gigi sebagai mitra mengenai pentingnya melakukan desinfeksi sebelum reparasi gigi tiruan. Karena pada saat preparasi gigi tiruan biasanya debu debu dari akrilik yang digerinda akan bisa menyebabkan resiko tertular infeksi. Dengan mengetahui lebih jelas pentingnya melakukan desinfeksi pada gigi tiruan sebelum dilakukan reparasi maka dapat menghindari terjadinya infeksi silang sehingga para teknisi gigi dapat melaksanakan pengelolaan kesehatannya secara mandiri.

\section{Solusi yang ditawarkan}

Berkaitan dengan permasalahan yang dialami oleh mitra, tim pelaksana pengabdian kepada masyarakat memberikan beberapa solusi. Solusi yang diberikan berupa penyuluhan tentang pentingnya melakukan desinfeksi pada saat reparasi gigi tiruan. Penyuluihan dilakukan dengan pemberian materiyang dilanjutkan tanyajawab dan demonstrasis serta pembahasan hasil penyuluhan sebagai evaluasi. Selain itu, penyuluhan dilakukan secara gratis atau tidak dipungut biaya.

$\mathrm{Hal}$ ini dilakukan dengan tujuan agar peserta lebih tertarik dan antusias dalam mengikuti penyuluhan yang diadakan. Kegiatan penyuluhan diberikan oleh para pengabdi yang berkompeten dengan bidang yang berkaitan dengan persoalan mitra.

Solusi yang diberikan diharapkan memberikan hasil sebagai berikut:

1. Mitra memiliki pengetahuan dan pemahaman tentang bahaya yang ditimbulkan akibat infeksi silang.

2. Diharapkan mitra mengetahui bahan yang dipergunakan untuk melakukan desinfeksi pada gigi tiruan.

3. Diharapkan mitra mengetahui cara melakukan desinfeksi pada reparasi gigi tiruan.

4. Diharapkan mitra mampu melakukan desinfeksi pada gigi tiruan saat akan dilakukan reparasi gigi tiruan dan dapat menerapkan hasil penyuluhan dalam aktivitasnya melakukan pekerjaan di laboratorium gigi.

\section{METODE}

Pelaksanaan kegiatan pengabdian kepada masyarakat ini meliputi tiga tahapan yaitu perencanaan, pelaksanaan, serta monitoring dan evaluasi.

Tahap pertama merupakan perencanaan kegiatan yang akan dilakukan. Proses perencanaan meliputi identifikasi kebutuhan, identifikasi potensi dan kelemahan yang ada, menentukan jalan keluar dan kegiatan yang akan dilakukan, dan membuat pengorganisasian kegiatan. Perencanaan disusun sendiri oleh masyarakat. Sedangkan tim pengabdian akan bertindak sebagai fasilitator. Pembuatan surat ijin pelaksanaan pengmas dilakukan dengankoordinasi ke RSUD Syaiful Anwar Malang dan laboratorium gigi Abadi di Kediri. Selain itu, sosialisasi kegiatan juga dilakukan ke RSUD Syaiful Anwar Malang dan laboratorium gigi Abadi di Kediri. Alat dan bahan yang diperlukan untuk pelaksanaan pengmas juga dipersiapkan. Peralatan yang disiapkan antara lain wadah untuk merendam gigi tiruan, bahan desinfeksi, pembuatan leaflet dan X-banner, buku panduan cara melakukan desinfeksi gigi tiruan, dan sertifikat Laboratorium gigi yang sudah mendapat pelatihan desinfeksi gigi tiruan serta konsumsi pada saat sosialisasi pengmas untuk peserta.

Tahap kedua merupakan pelaksanaan kegiatan. Kegiatan dilaksanakan pada laboratorium gigi sesuai dengan yang telah direncanakan. Sedangkan tim pengabdian akan bertindak sebagai fasilitator.

Pada tahap ketiga, dilakukan monitoring dan evaluasi kegiatan. Proses ini juga dilakukan sendiri oleh laboratorium gigi yang sudah mendapat penyuluhan. Tim pengabdian akan bertindak sebagai fasilitator.

Belajar mengaplikasikan kebiasaan baru membutuhkan waktu dan kesabaran, terutama bagi para teknisi gigi yang sudah bekerja selama bertahun-tahun. Yang biasa mereka lakukan setelah gigi tiruan yang patah diterima langsung akan dilakukan reparasi. Tidak pernah dilakukan desinfeksi terlebih dahulu. Tetapi setelah diadakan sosialisasi maka mereka diharapkan akan melakukan tindakan desinfeksi terlebih dahulu sebelum dan setelah tindakan melakukan reparasi pada gigi tiruan. Tentu hal tersebut bukan merupakan hal yang mudah untuk dilakukan. Beberapa hari sampai beberapa minggu merupakan periode penyesuaian agar diperoleh adaptasi yang disebabkan karena perubahan kebiasaan. Setelah terbiasa dianjurkan untuk selalu melakukannya demi kesehatan mereka sendiri. Untuk melakukan sosialisasi diperlukan dua tahap yaitu persiapan dan cara melakukan desinfeksi. 
Langkah persiapan yang dilakukan sebelum melakukan reparasi pada gigi tiruan adalah dengan melakukan desinfeksi pada gigi tiruan. Yang dipersiapkan adalah menyediakan alat dan bahan yang diperlukan untuk melakukan desinfeksi. Ada beberapa cara untuk mensterilkan atau membersihkanresinakrilik darikumanakibatinfeksi silang yaitu ada dalam saliva dan menggantikan kalsium yang diperlukan sebagai perekat dengan cara pertama yaitu dicelupkan ke dalam larutan desinfektan. Cara kedua dengan disemprot (spray) dengan bahan desinfektan, dan cara ketiga yaitu dengan menggunakan microwave. Untuk sterilisasi gigi tiruan, ADA merekomendasikan perendaman gigi tiruan dalam desinfektan. Bahan desinfektan yang direkomendasi oleh ADA adalah alkalin glutaraldehid sedangkan desinfektan yang lazim digunakan rumah sakit di Indonesia adalah klorheksidin dan sodium hipoklorit.

Setelah gigi tiruan yang patah diterima, selanjutnya gigi tiruan dicuci dengan sabun dan dibilas dengan air kemudian dikeringkan dengan kertas tisu lalu dilakukan desinfeksi dengan menggunakan bahan khlorheksidin dengan cara disemprot pada seluruh permukaan gigi tiruan. Pemilihan bahan desinfeksi khlorheksidin karena bahan tesebut mudah didapat dan tidak menyebabkan perubahan sifat fisik akrilik secara signifikan. Pemilihan cara dengan disemprot (spray) sebagai salah satu cara membersihkan resin akrilik dari bakteri yang sudah teruji juga efektif, karena tidak menimbulkan perubahan keakuratan dimensi dari permukaan. Pembuatan laporan kegiatan pengabdian masyarakat dilakukan setelah sosialisasi kegiatan selesai dilaksanakan.

\section{HASIL DAN PEMBAHASAN}

Kegiatan pengabdian masyarakat yang sudah dilaksanakan yaitu tahap persiapan berupa rapat koordinasi dengan anggota tim pengabdian, mengurus perijinan, sosialisasi ke laboratorium mitra yaitu beberapa laboratorium gigi di Malang dan di Kediri. Pembelian alat dan bahan yang dibutuhkan untuk kegiatan, pembuatan leaflet, X-banner, pembuatan buku panduan cara melakukan desinfeksi gigi tiruan, serta menyiapkan daftar hadir juga sudah dilakukan.

Pembuatan surat pernyataan kesediaan laboratorium gigi yang akan dituju bertujuan untuk menerima tim pelaksana penyuluhan yang akan melakukan pelaksanaan pengabdian masyarakat di laboratoriumnya. Penyediaan alat dan bahan yang diperlukan untuk pelaksanaan pengabdian masyarakat yang dilakukan oleh ibu Sri Redjeki Indiani drg.,Mkes.

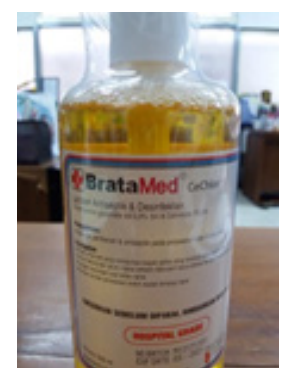

Gambar 1. Bahan desinfeksi gigi tiruan

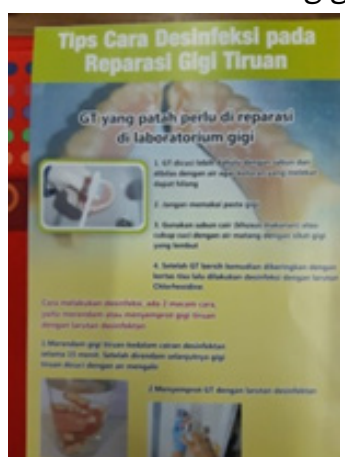

Gambar 2. Leaflet cara desinfeksi gigi tiruan

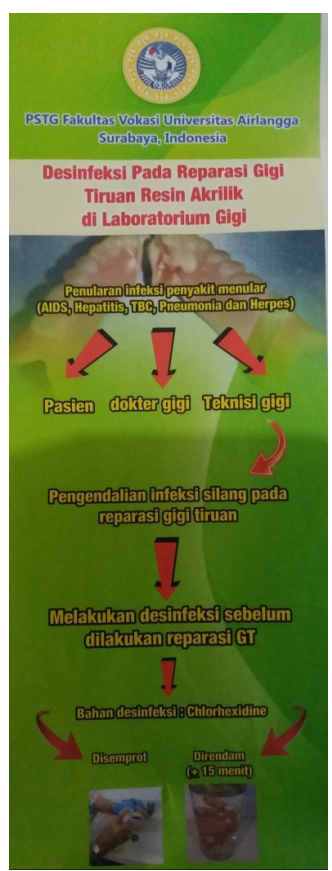

Gambar 3. X-banner pengabdian kepada masyarakat

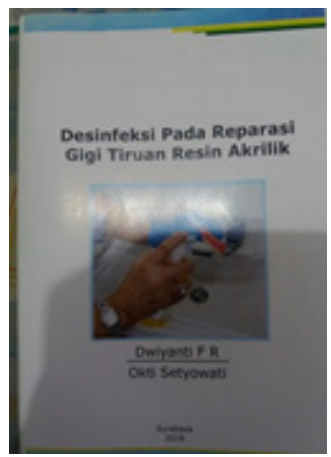

Gambar 4. Sampul buku panduan 
Pelaksanaan program pengabdian masyarakat dilakukan pada 2 lokasi yaitu Malang dan Kediri.

\section{a. Pelaksanaan di Malang (10 juli 2019)}

Tahap pertama yang dilakukan adalah mengumpulkan para teknisi gigi yang berada di Malang. Yang bersedia untuk mengikuti program sebanyak 3 orang yang bekerja di RSUD Syaiful Anwar Malang dan mereka masing masing mempunyai laboratorium milik pribadi. Pada tahap ini, kegiatan yang dilakukan adalah sosialisasi penggunaan bahan desinfeksi saat reparasi gigi tiruan resin akrilik (Gambar 5A).

Edukasi tentang dampak yang terjadi apabila gigi tiruan tidak dilakukan desinfeksi disampaikan oleh Dwiyanti FR, drg.M.Kes. Laboratorium gigi yang mendapatkan penyuluhan yaitu laboratorium gigi yang berada RSUD Syaiful Anwar, Malang (Gambar 5B).

Kegiatan dilanjutkan dengan demonstrasi cara menggunakan desinfektan oleh Okti Setyowati, drg.M.Kes. dan Endang Kusdarjanti, drg. M.Kes. Setelah kegiatan selesai diberikan sertifikat kepada mitra oleh Dwiyanti FR, drg., M.Kes.

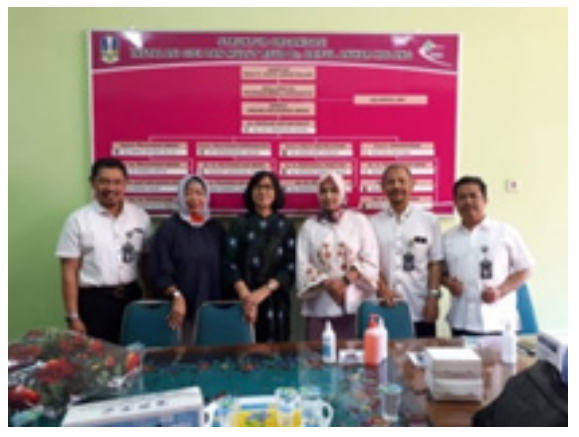

Gambar 5A. Para teknisi gigi di RSUD Syaiful Anwar, Malang bersama tim pengabdian masyarakat

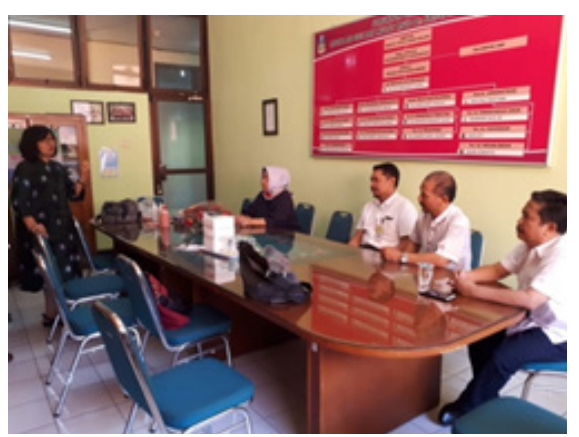

Gambar 5B. Penyuluhan pada laboratorium gigi di Malang

\section{b. Pelaksanaan di Kediri (31 Juli 2019)}

Tahap kedua yang dilakukan adalah mengumpulkan para teknisi gigi yang berada di Kediri. Yang bersedia untuk mengikuti program sebanyak 11 orang, dari 3 laboratorium gigi (Gambar 5C).
Pelaksanaan kegiatan yang dilakukan yaitu memberikan sosialisasi kepada para teknisi gigi. Sosialisasi tentang dampak yang diakibatkan apabila gigi tiruan tidak didesinfeksi, disampaikan oleh Dwiyanti FR,drg., MKes dan Okti Setyowati, drg., MKes. Sosialisasi dilakukan di laboratorium Abadi, Kediri (Gambar 5D). Kegiatan dilanjutkan demonstrasi cara menggunakan desinfektan oleh Endang Kusdarjanti drg., M.Kes.

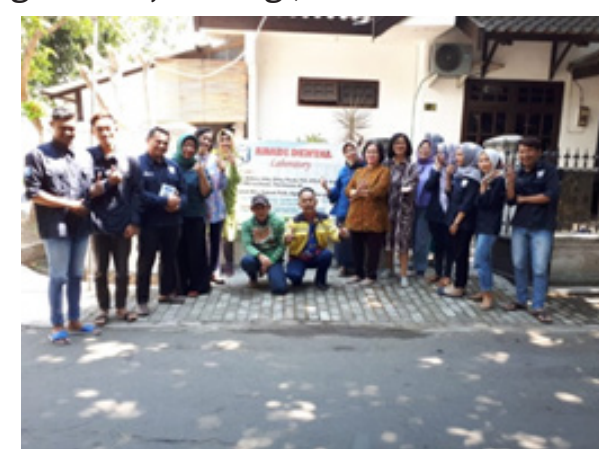

Gambar ${ }_{5} C$. Para teknisi gigi yang menerima sosialisasi pada laboratorium gigi di Kediri dan tim pengabdi

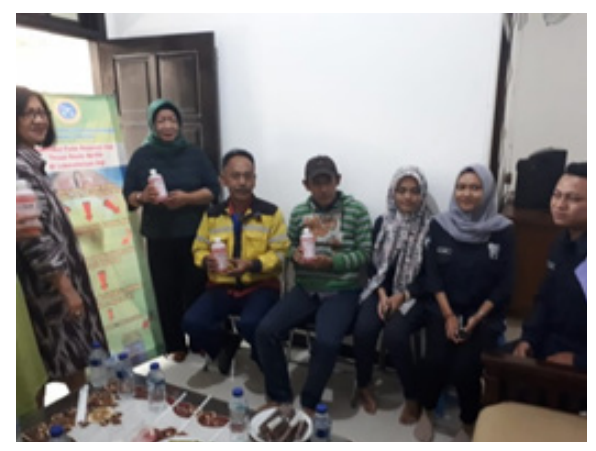

Gambar 5D. Para teknisi gigi sedang menerima sosialisasi pada laboratorium gigi di Kediri

Sosialisasi dilakukan dengan memberikan pengetahuan tentang langkah persiapan yang harus dilakukan sebelum melakukan reparasi pada gigi tiruan yaitu dengan melakukan desinfeksi pada gigi tiruan. Ada beberapa cara untuk mensterilkan atau membersihkan resin akrilik dari kuman akibat infeksi silang yaitu ada dalam saliva dan menggantikan kalsium yang diperlukan sebagai perekat dengan cara pertama yaitu dicelupkan ke dalam larutan desinfektan. Cara kedua dengan disemprot (spray) dengan bahan desinfektan, dan cara ketiga yaitu dengan menggunakan microwave.

\section{KESIMPULAN DAN SARAN}

Berdasarkan hasil kegiatan pengabdian masyarakat di lokasi mitra, maka dapat disimpulkan bahwa selama ini laboratorium gigi belum melakukan tindakan desinfeksi pada saat melakukan reparasi gigi tiruan. Dengan 
adanya penyuluhan dan pelatihan pada program kemitraan masyarakat ini, para teknisi gigi mengetahui pentingnya melakukan tindakan desinfeksi pada gigi tiruan untuk mencegah infeksi silang, sehingga selanjutnya mitra akan melakukan tindakan desinfeksi seperti yang disarankan.

Saran yang dapat kami rekomendasikan antara lain bagi lembaga PTGI (Persatuan Teknisi Gigi Indonesia) dan laboratorium gigi. PTGI diharapkan memberikan kesempatan dan pengetahuan dengan memberikan penyuluhan tentang bahayabahaya infeksi silang pada para teknisi gigi dengan serius agar bahaya-bahaya yang disebabkan karena infeksi silang dapat dipahami dengan baik oleh masyarakat, sehingga dapat mengurangi resiko tertular.

Laboratorium gigi yang bersangkutan juga diharapkan mau dan mampu mengembangkan dan meneruskan program ini dan menjalankannya rutin di laboratoriumnya sehingga dapat mengurangi terjadinya infeksi silang.

\section{UCAPAN TERIMA KASIH}

Penulis mengucapkan terima kasih kepada Fakultas Vokasi Universitas Airlangga atas bantuan dana melalui Pengabdian Kepada Masyarakat tahun 2019. Penulis menyatakan tidak ada konflik kepentingan dengan pihak-pihak yang terkait dalam kegiatan pengabdian kepada masyarakat ini.

\section{DAFTAR PUSTAKA}

Al-Fahdawi I, Al-Huwaizi H, Fatah NA. The effect of the polyvinyl pyrrolydone (PVP) addition on surface hardness and impact strength properties of heat cured acrylic resin denture base materials. J Bagh College Dent, 2009; 21(3), 1-5.

Anusavice KJ. Phillips buku ajar ilmu bahan kedokteran gigi.Alihbahasa; Johan Arief Budiman, Susi Purwoko. Edisi 10. Jakarta : EGC, 2004; p. 29-61, 192-222.

Badrian H, Ghasemi E, Khalighnejad N, Hosseini N. The effect of three disinfection materials on alginate impression by spray method.ISRN Dental 2012; 695151.Published online 2012 July 25.

David, Munadziroh E. Perubahan warna lempeng resin akrilik yang direndam dalam larutandesinfektan sodium hypochlorite dan klorhexidin. Dent J 2005; 38 (1): 36-40.

Ferraz CC, Gomes BP, ZaaAA, Teixeiera FB. Comparative study of the antimicrobial efficacy of chlorhexidine gel, chlorhexidine solution and sodium hypochlorite as endodontic irrigants; Braz DentJ 2007; 18(4): 294-8.

Fluent MT, Molinari JA Molinari JA. How the Dental Laboratory Provides Infection Control.AEGIS Dental Network 2013; 9(2).

Hussen AM, Rejab LT, Abbood LN. The effect of microwave disinfection on the dimensional change of acrylic resin. Al-Rafidain Dent J 2008; 8 (1): 38-43.

Hutasoit, Muktar. Perubahan kekerasan resin akrilik setelah perendaman dalam larutan desinfektan sodium hipoklorit 0,5\%., Universitas Sumatra Utara,USU Institusional Repository. 2010.

KentersN, GottliebT. HopmanJ, Mehtar S, SchweizerM, Tartari E. An international survey of cleaning and disinfection practices in thehealthcare environment. Journal of Hospital Infection;2018(100):236-241.

Manappallil JJ. Basic dental materials.2nd ed. New Delhi: Jaypee Brothers Medical Publishers; 1998. p. 98-137.

Martindale.The extra pharmacopoea. 28th ed. London: The Pharmaceutical Press; 1982.p. 554-6, 564-5. A, Schmidt CB, Walber LF, Shinkai RSA. Microwave assisted disinfection method in dentistry. Braz Dent.J 2006; 17 (3):195-200.

Mc Cabe JF. Anderson's applied dental materials. 6th ed. Edinburgh: Blackwell Scientific Publication; 1984. p. 83-91.

Mc Donnell G, Russell AD. Antiseptics and disinfectant: activity, action and resistance. Clinical biology review 1999; 12 (1): 147-79.

Noort RV.Introduction to dental materials. London: Mosby; 2010. p. 183-5.

Powers JM. Dental materials properties and manipulation. 9th ed. Missouri: Mosby Inc; 2008.p. 31-2; 286-94.

Salviaa ACRD, Matildea FS, Rosab FCS, Kimpara $\mathrm{ET}$, Jorge $\mathrm{AOCa}$, Balduccial, Koga-lto CY. Disinfection protocols to prevent crosscontamination between dental officesAnd prosthetic laboratories. Journal of infection and Public Health;2013(6): 377-382

Sande MA. Point source epidemic of mycoplasma pneumonia infection in a prosthodontic laboratory.Am Respir Dis 1975; 112: $213-7$.

Shah AH, Wyne AH. Cross - Infection Control In Dentistry: A Review. Pakistan Oral \& Dental Journal 2010, 30(1):168-174.

TanumihardjaM.Larutan irigasi saluran akar. Dentofasial 2010; 9 (2): 108-15.

Yagiela JA, Frank DJ, Enid. Pharmacology and therpeutics for dentistry 5th ed., St Louis, Missouri: Westline Industrial Drive; 2004. p. 756-61. 